\title{
ROCK PAINTINGS OF MAMMALS AT CENTRAL, BAHIA, BRAZIL ${ }^{1}$
}

\author{
Maria da Conceição de M.C. Beltrão ${ }^{2,3}$ \\ Martha Locks ${ }^{2}$
}

\begin{abstract}
Rock paintings of mammals have been studied in five of the 243 localities contained within the $270,000 \mathrm{~km}^{2}$ Archeological Region of Central, Bahia. From features of external morphology, it was possible to recognize 11 mammals represented in the paintings: for five, to attribute the species; another five, the genera; and, for one, merely the family. This study aims to underline the importance of prehistoric man's contribution, by way of these rock paintings, to our knowledge of the mammals depicted, both taxonomically and in terms of their distribution within the bounds of the Project in the State of Bahia.

KEY WORDS. Mammals, rock paintings, morphology, archeological region, Bahia, Brazil
\end{abstract}

Project Central embraces an area of $270,000 \mathrm{~km}^{2}$ containing 243 localities in the western and eastern Chapada Diamantina in northeastern Bahia State. Its epicenter lies in the municipality of Central $\left(11^{\circ} 9^{\prime} \mathrm{S}\right.$ and $\left.43^{\circ} 7^{\prime} \mathrm{W}\right)$ on the limestone uplands of the Chapada Diamantina.

The rock paintings were found at sites denominated grottoes and gorges, on Precambrian quartzite rocks or on limestone rocks of the Salitre and Caatinga formations in the municipalities of Central, Xique-Xique, Uibaí, Gentio do Ouro $\left(11^{\circ} 03^{\prime}-11^{\circ} 19^{\prime} \mathrm{S}\right.$ and $\left.42^{\circ} 04^{\prime}-42^{\circ} 28^{\prime} \mathrm{W}\right)$ and Morro do Chapeú $\left(11^{\circ} 26^{\prime}-11^{\circ}\right.$ $29^{\prime} \mathrm{S}$ and $\left.41^{\circ} 16^{\prime}-41^{\circ} 17^{\prime} \mathrm{W}\right)$ (Fig. 1; Tab. 1).

The prehistoric paintings of mammals in the Archeological Region of Central range in size from $2 \mathrm{~cm}$ to $130 \mathrm{~cm}$. The animals' outlines are blocked in with single colors and generally without detail work, attention being limited to essentials: head, neck, ears, members and tail (BELTRÃO \& LIMA, 1986). The paintings are stylized although some show sufficient detail to permit taxonomic recognition of deer, anteater, tapir, etc. The results presented here relate to only five of the 243 localities covered by Project Central.

1) Financed partly by the National Research Council $(\mathrm{CNPq})$ and the Study and Research Finance Agency (FINEP).

2) Departamento de Antropologia, Museu Nacional do Rio de Janeiro, Quinta da Boa Vista, 20940-040 Rio de Janeiro, Rio de Janeiro, Brasil.

3) Researcher of the Brazilian National Research Council (CNPq). 


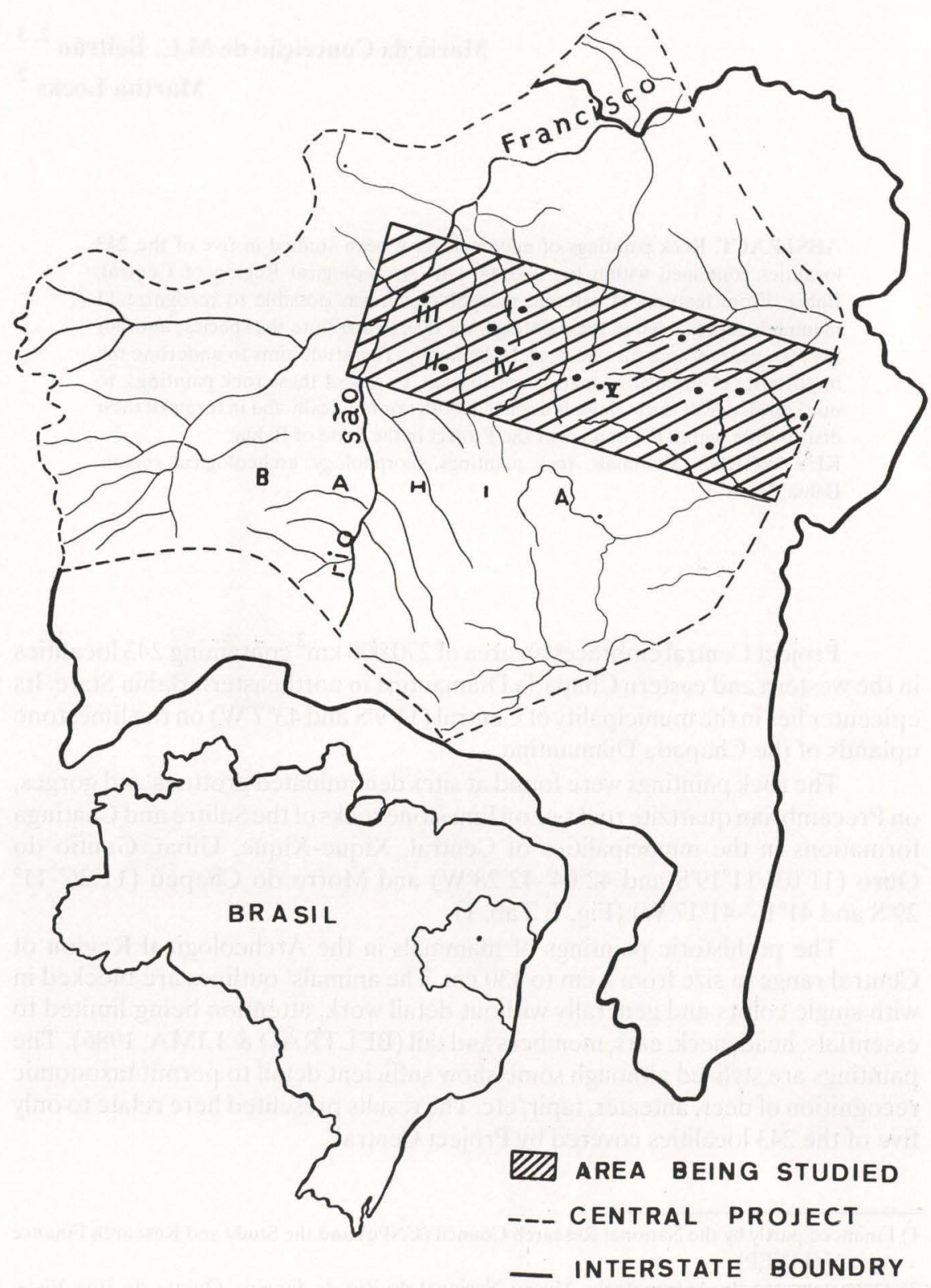

Fig. 1. Location of rock paintings by country in the Archeological Region of Central: (I) Central; (II) Xique-Xique; (III) Uibaí; (IV) Gentio do Ouro; (V) Morro do Chapéu. 
Table I. Sites of rock paintings. Project Central according to map of Brazil. Scale: 1:100,000,000. Font Fundação IBGE (Instituto Brasileiro de Geografia e Estatística), Folha SC-23-X-II (Central).

\begin{tabular}{|c|c|c|c|c|c|c|}
\hline District & Location & Sites & Lat (S) & Long (W) & Mammals & Figure \\
\hline Central & Fazendinha & $\begin{array}{l}\text { Boqueirão da } \\
\text { Fazendinha }\end{array}$ & $11^{\circ} 13^{\prime}$ & $42^{\circ} 13^{\prime}$ & Mazama sp. & $10 \mathrm{~A}$ \\
\hline \multirow{5}{*}{ Xique-Xique } & $\begin{array}{l}\text { Capoeira da } \\
\text { Serra }\end{array}$ & Toca do Tatu & $11^{\circ} 04^{\prime}$ & $42^{\circ} 04^{\prime}$ & Felis sp. & $14 \mathrm{D}$ \\
\hline & Pequeno & $\begin{array}{l}\text { Grota do } \\
\text { Pequeno }\end{array}$ & $11^{\circ} 08^{\prime}$ & $42^{\circ} 22^{\prime}$ & Felis sp. & $14 \mathrm{~A}$ \\
\hline & \multirow{3}{*}{$\begin{array}{l}\text { Riacho da } \\
\text { Grota dos } \\
\text { Bois }\end{array}$} & Grota Bonita & $11^{\circ} 03^{\prime}$ & $42^{\circ} 26^{\prime}$ & P. macrocephalus & $12 \mathrm{~A}$ \\
\hline & & $\begin{array}{c}\text { Toca dos } \\
\text { Peixes }\end{array}$ & $11^{\circ} 03^{\prime}$ & $42^{\circ} 26^{\prime}$ & $\begin{array}{l}\text { Cervidae } \\
\text { Dasypus sp. }\end{array}$ & $\begin{array}{l}7 \mathrm{~B} \\
5 \mathrm{E}\end{array}$ \\
\hline & & $\begin{array}{l}\text { Boqueirão dos } \\
\text { Veados }\end{array}$ & - & - & $\begin{array}{l}\text { M. tridactyla } \\
\text { B. dichotomus }\end{array}$ & $\begin{array}{l}3 \mathrm{~B} \\
8 \mathrm{~A}\end{array}$ \\
\hline \multirow[t]{2}{*}{ Uibaí } & \multirow{2}{*}{$\begin{array}{l}\text { Riacho da } \\
\text { Fonte } \\
\text { Grande }\end{array}$} & Fonte Grande I & $11^{\circ} 19^{\prime}$ & $42^{\circ} 09^{\prime}$ & $\begin{array}{l}\text { Cervidae } \\
\text { Mazama sp. } \\
\text { Dasypus sp. }\end{array}$ & $\begin{array}{c}7 \mathrm{D} \\
10 \mathrm{~B}, \mathrm{C} \\
5 \mathrm{C}, \mathrm{D}\end{array}$ \\
\hline & & Fonte Grande II & $11^{\circ} 19^{\prime}$ & $42^{\circ} 09^{\prime}$ & $\begin{array}{l}\text { Cervidae } \\
\text { Cricetidae } \\
\text { Felis sp. }\end{array}$ & $\begin{array}{l}7 \mathrm{~A}, \mathrm{C} \\
13 \mathrm{~A} \\
14 \mathrm{C}\end{array}$ \\
\hline \multirow{2}{*}{$\begin{array}{l}\text { Gentio do } \\
\text { Ouro }\end{array}$} & Mulungu & Mulungu & $11^{\circ} 14^{\prime}$ & $42^{\circ} 26^{\prime}$ & T. terrestris & $6 \mathrm{~A}, \mathrm{~B}, \mathrm{C}$ \\
\hline & $\begin{array}{l}\text { Fazenda } \\
\text { Amores }\end{array}$ & $\begin{array}{l}\text { Toca do } \\
\text { Caldeirão }\end{array}$ & $11^{\circ} 16^{\prime}$ & $42^{\circ} 20^{\prime}$ & $\begin{array}{l}\text { Dasypus sp. } \\
\text { Felis sp. }\end{array}$ & $\begin{array}{l}5 \mathrm{~A}, \mathrm{~B} \\
14 \mathrm{~B}\end{array}$ \\
\hline \multirow[t]{2}{*}{$\begin{array}{r}\text { Morro do } \\
\text { Chapeu }\end{array}$} & Serra Nua & Serra Nua & $11^{\circ} 29^{\prime}$ & $41^{\circ} 17^{\prime}$ & $\begin{array}{l}\text { O. bezoarticus } \\
\text { K. rupestris } \\
\text { Tayassu sp. }\end{array}$ & $\begin{array}{r}9 \mathrm{~A} \\
13 \mathrm{C} \\
11 \mathrm{~A}\end{array}$ \\
\hline & $\begin{array}{l}\text { Lagoa da } \\
\text { Velha }\end{array}$ & $\begin{array}{r}\text { Toca da } \\
\text { Corça }\end{array}$ & $11^{\circ} 26^{\prime}$ & $41^{\circ} 16^{\prime}$ & B. dichotomus & $8 \mathrm{~B}$ \\
\hline
\end{tabular}

\section{METHODS}

The comparative study obeyed the following methodology:

1. All the illustrations of rock paintings presented here were produced from photos and tracings made in the field and later reduced where necessary. The drawings so derived were used for comparison with Sub-Recent and Recent mammals identified with Brazil and, particularly, with the State of Bahia.

2. Make outline drawings of the mammals (Fig. 3A);

3. Overlay drawings on rock paintings (Fig. 3B);

4. Observe characteristics like shape and size of head (ears, face, mouth, etc.), neck, trunk, members, tail and details of feet (plantigrade, digitigrade, unguligrade, didactyl, tridactyl, etc.); that is, all possible features of external morphology (Figs 2A, B, C, D; 4A, B, C, D, E, F).

5. Make drawings for comparison, adopting the same technique as used in the rock painting; i.e., block fill painting (Figs 3C; 5F; 6D; 8C; 9B; 10D; 11B; 12B; 13B, D; 14E.

The above methodology enabled us to identify the species in most cases. 

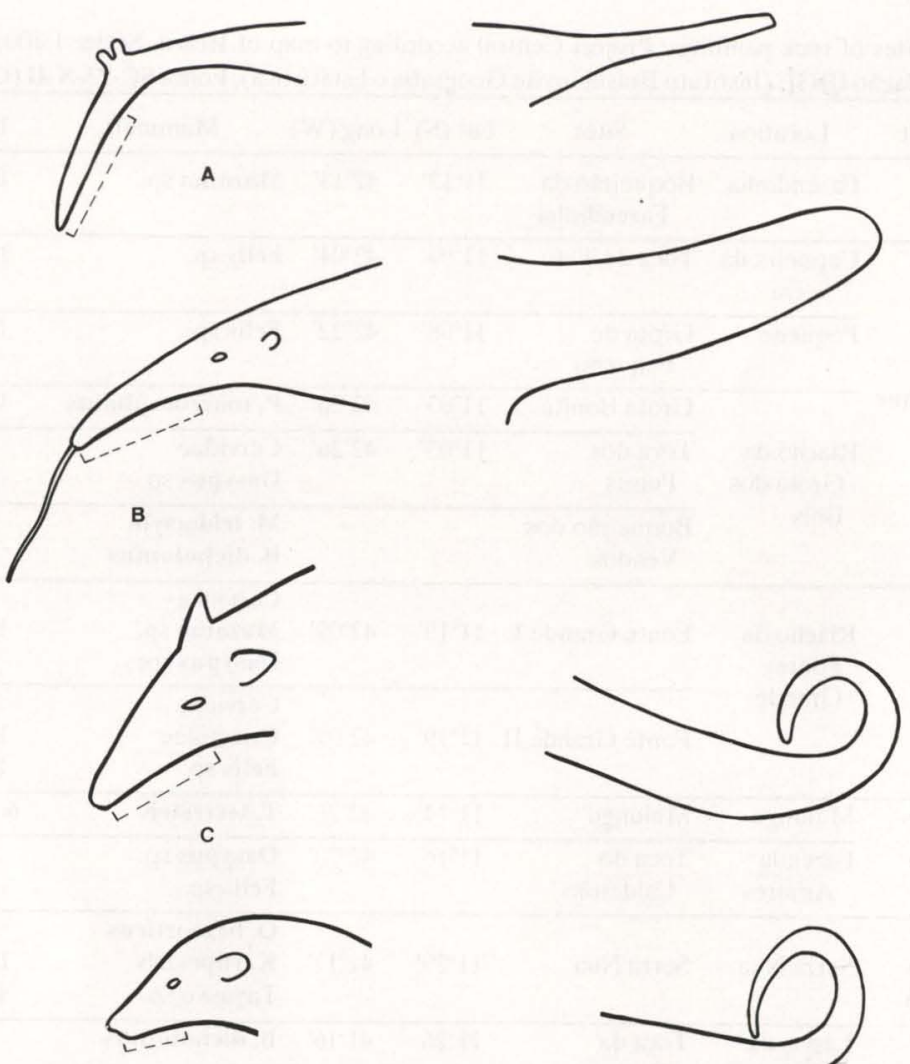

D

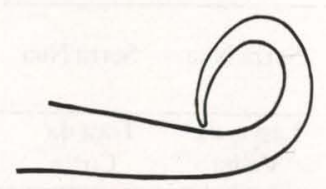

Fig. 2. (A) Comparison of head (showing length of snout) and tail in the rock painting with those of three species of anteater: (B) Giant Anteater; (C) Collared Anteater; (D) Silky Anteater.

\title{
RESULTS AND DISCUSSION
}

The system adopted is based on SIMPSON (1945), CABRERA (1957, 1960) and HOFFMANN (1982). Here we shall present the taxonomy of the species found:

\author{
EDENTATA Cuvier, 1798 \\ Myrmecophagidae Bonaparte, 1838 \\ Myrmecophaga tridactyla Linnaeus, 1758 \\ (Fig. 3C, D)
}

In the rock drawing (Fig. 3B) the form of a giant anteater can be clearly seen, the head elongated and tubular although the cranium is small. The mouth opening is at the end of the snout and it has a wormlike tongue (SANTOS, 1984). 

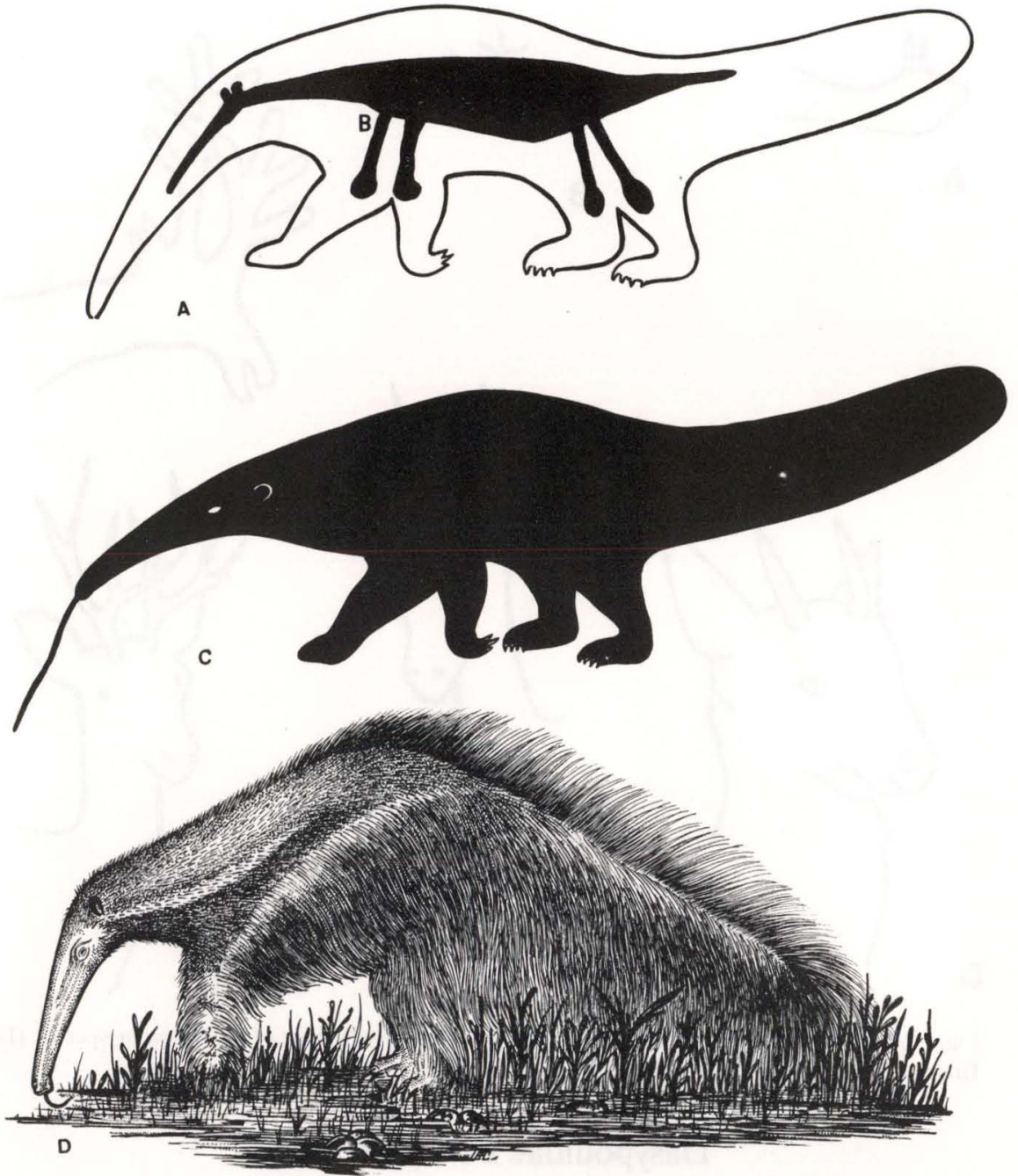

Fig. 3. (B) Drawing of giant anteater overlaıd on rock paintıng; (A) si. waaciyıa used tor comparison.

The tail is long, not prehensile and completely covered with long, stiff hair. The forefeet are curved in towards the palm and the hindfeet are plantigrade (CABRERA \& YEPES, 1940).

The animal is known to have existed since the Upper Pliocene in Argentina. Its habitat extends from the Guianas and Venezuela down to Peru and northern Argentina (Salta, Formosa, Chaco and Misiones) and southern Brazil (KOWALSKI, 1981). 


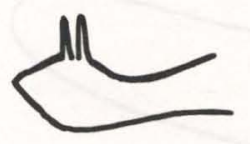

A

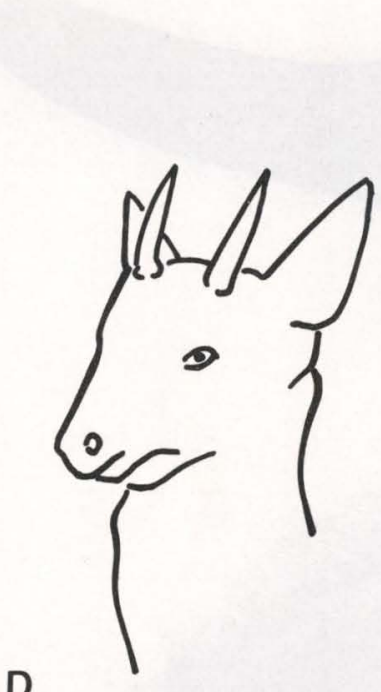

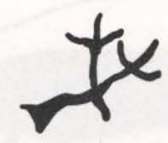

B

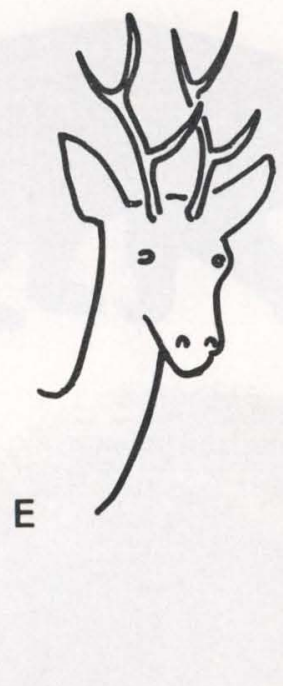

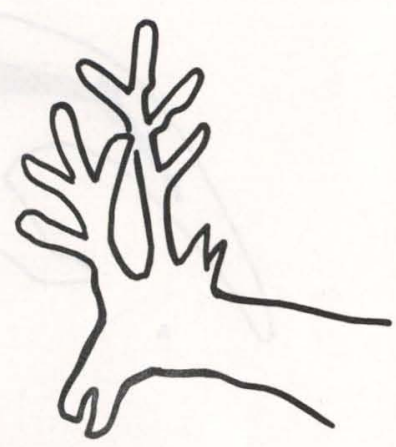

C

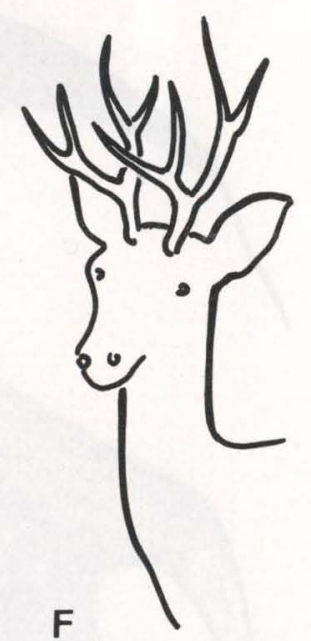

Fig. 4. (A-C) Comparison of the horns in the rock painting with those of the following species: (D) Brown Brocket; (E) Pampas Deer; (F) Marsh Deer.

\section{Dasypodidae Bonaparte, 1838}

This family contains all the extant (and most of the extinct) armadillos, whose shells, composed of numerous plates, are divided into three parts (fore, middle and hind). The mid-region comprises several mobile transverse bands. The dorsal regions of the head and tail are also covered with plates. The head is elongated, the snout sharp, the tongue flat and extensile. The members are short, bearing a variable number of toes with curved claws.

Representatives of this family have existed in South America since the Paleocene. There are six genera in Brazil, two extinct. In the region, we have already identified plates belonging to the species $\uparrow$ Propaopus sulcatus (Lund, 1841), †Pampatherium humboldti (Lund, 1841) - which are extinct forms Euphractus sexcinctus (Linnaeus, 1758), the six-banded armadillo; Dasypus 

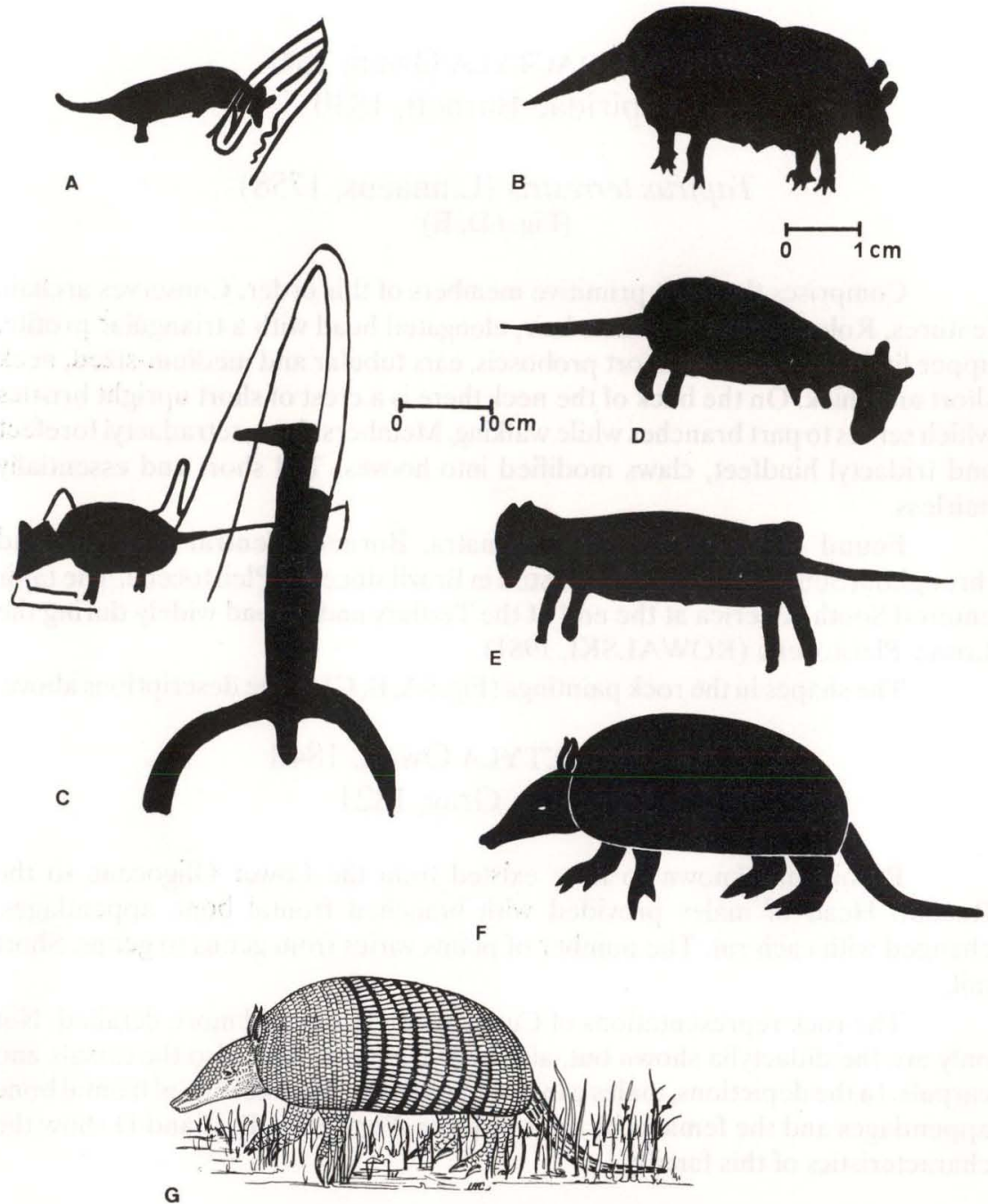

Fig. 5. (A-E) Rock paintings of armadillos; (F-G) E. septemcinctus used for comparison.

septemcinctus Linnaeus, 1758, the common or seven-banded armadillo (Fig. 5F, G); Cabassous unicinctus (Linnaeus, 1758) and Tolypeutes tricinctus (Linnaeus, 1758), the three-banded armadillo. Given the similarity in external outlines, the rock paintings could correspond to any of these except the latter species which has a short tail (Fig. 5A, B, C, D, E).

To judge by the tail however, which is depicted long we believe these to be representations of the genus Dasypus Linnaeus, 1758 (Fig. 5F, G). 


\section{PERISSODACTYLA Owen, 1848 \\ Tapiridae Burnett, 1830}

\section{Tapirus terrestris (Linnaeus, 1758) \\ (Fig. 6D, E)}

Comprises the most primitive members of this order. Conserves archaic features. Robust structure, short hair, elongated head with a triangular profile, upper lip in the form of a short proboscis, ears tubular and medium-sized, neck short and thick. On the back of the neck there is a crest of short upright bristles which serves to part branches while walking. Members short, tetradactyl forefeet and tridactyl hindfeet, claws modified into hooves. Tail short and essentially hairless.

Found in Southeast Asia, Sumatra, Borneo, Central America and throughout South America. Has existed in Brazil since the Pleistocene. The tapir entered South America at the end of the Tertiary and spread widely during the Lower Pleistocene (KOWALSKI, 1981).

The shapes in the rock paintings (Fig. 6A, B, C) fit the descriptions above.

\section{ARTIODACTYLA Owen, 1848 Cervidae Gray, 1821}

Ruminants, known to have existed from the Lower Oligocene to the Recent. Head of males provided with branched frontal bone appendages, changed with each rut. The number of points varies from genus to genus. Short tail.

The rock representations of Cervidae are richer and more detailed. Not only are the didactylia shown but, almost as a general rule, also the tarsals and carpals. In the depictions, males can be identified by the presence of frontal bone appendages and the females by their absence. Figure 7A, B, C and D show the characteristics of this family.

\section{Blastocerus dichotomus (Illiger, 1815)}

Fig. 8C, D

This is the largest of our cervids, with big antlers, the beam of which branches into two at a short distance from the burr, each branch also being two-tined. That is, the species has four, six or more points (CARVALHO, 1979) and a sturdy body.

The features in the rock paintings in figure $8 \mathrm{~A}$ and $\mathrm{B}$ enable us to identify them as this species.

Besides the hundreds of depictions of $B$. dichotomus in which morphological features are well defined, both the hunting of this animal and its behavior are also illustrated (BELTRÃO \& LOCKS, 1993). 
Since the Pleistocene, the species has inhabited central South America, the states of Goias, inland Bahia, Mato Grosso, inland Rio Grande do Sul, the extreme east of Bolivia and of Paraguay, down to the Argentinian Chaco.
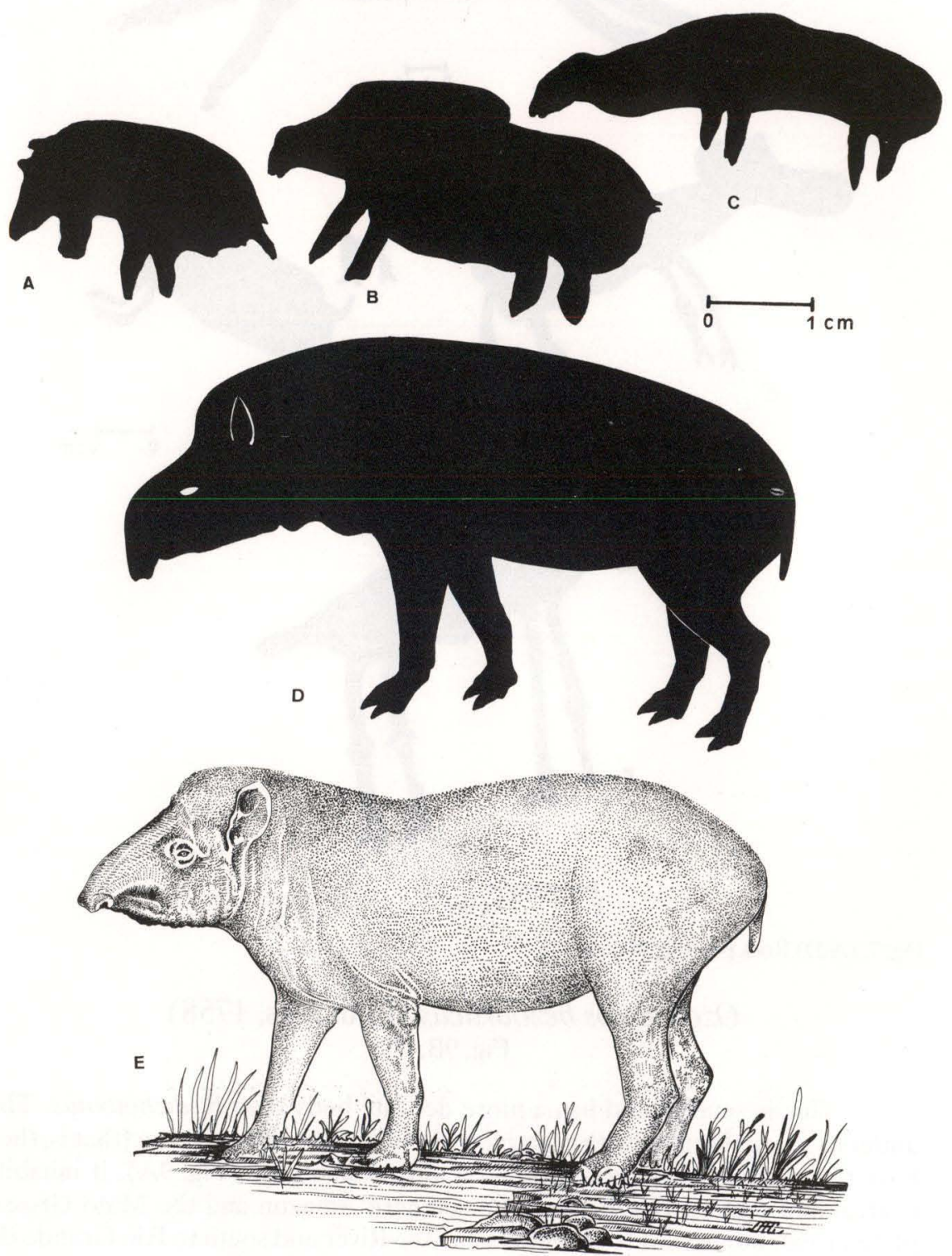

Fig. 6. (A-C) Rock painting of a tapir; (D-E) T. terrestris used for comparison. 


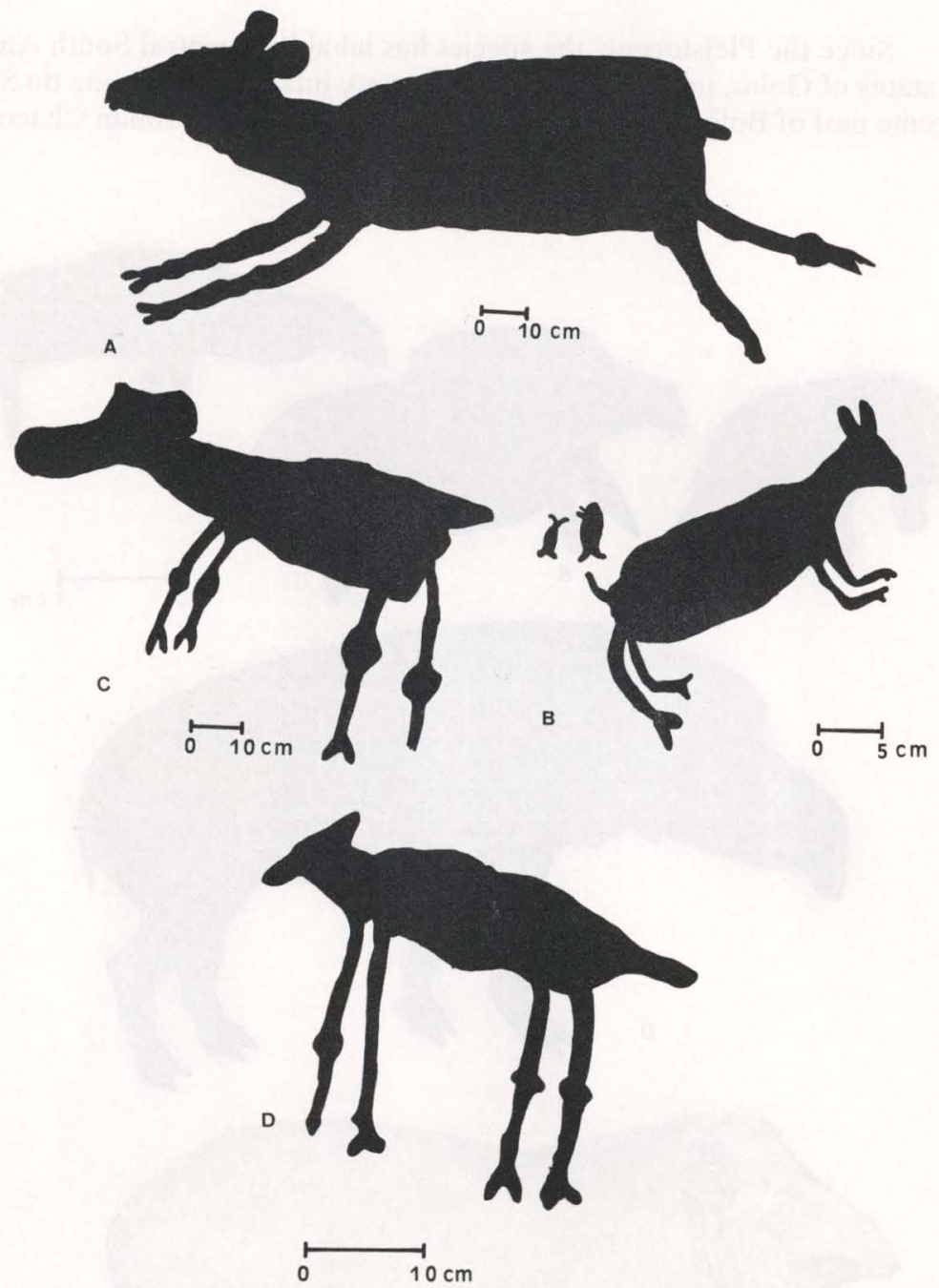

Fig. 7. (A-D) Rock painting of deer.

\section{Ozotoceros bezoarticus (Linnaeus, 1758)}

Fig. 9B, C

This is smaller and has a more delicate body than B. dichotomus. The antlers too are slimmer, with a simple fork and two-branched beam (that is, they have three points) clearly represented in rock paintings (Fig. 9A). It inhabits central and eastern Brazil, from the southern Amazon and the Mato Grosso plateau, extending west to the São Francisco River and south to Rio Grande do Sul State and Uruguay. In the Pleistocene in Brazil, they were to be found in the limestone caves of the Rio das Velhas valley, Minas Gerais State. 


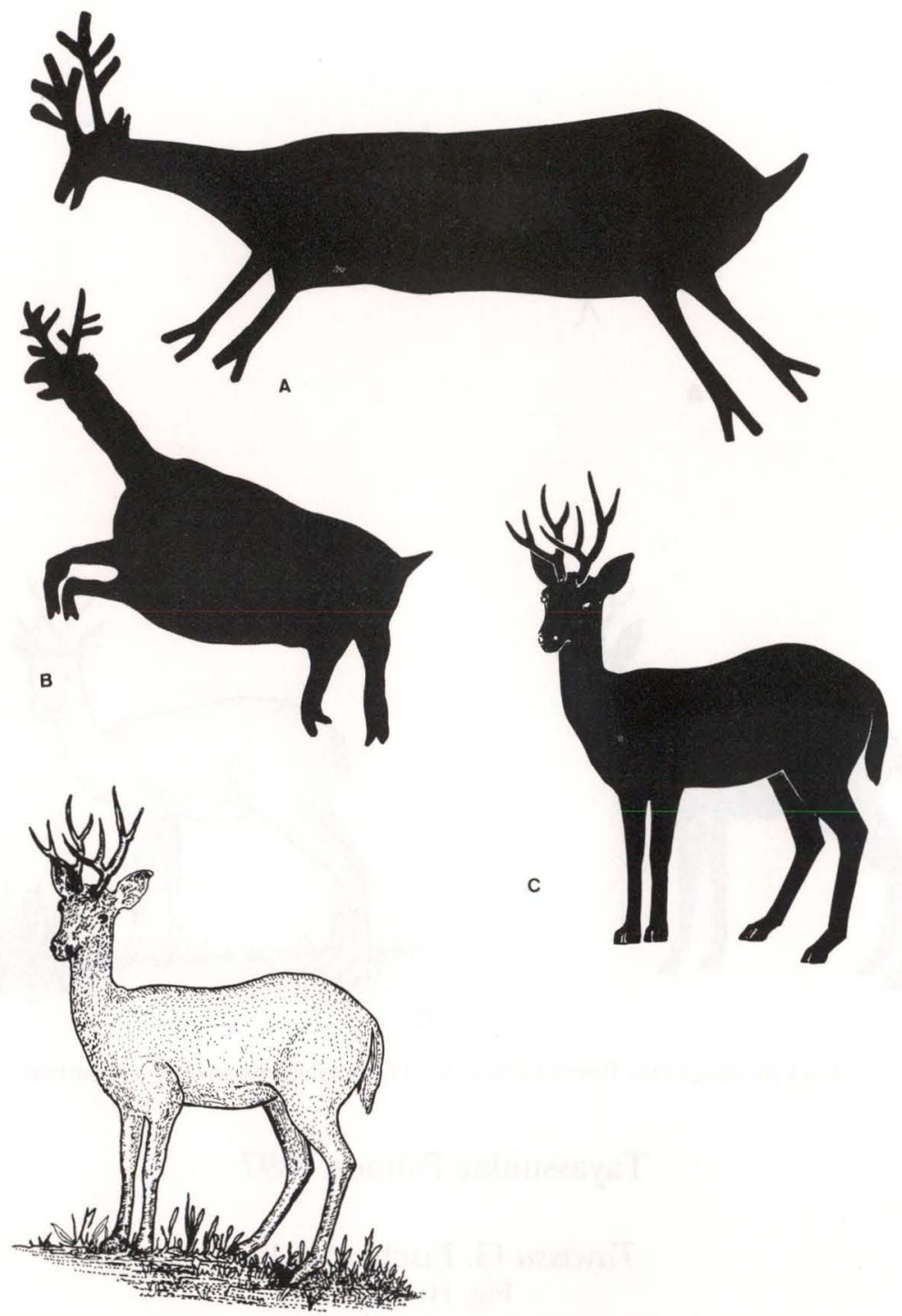

Fig. 8. (A-B) Rock painting of the Marsh Deer; (C-D) B. dichotomus used for comparison.

\section{Mazama Rafinesque, 1817 \\ Fig. 10D, E}

This genus comprises the smallest and most graceful cervids among our fauna. They have one-pointed horns as in figure $8 \mathrm{~A}, \mathrm{~B}$ and $\mathrm{C}$. The shape of the ears differs from that in figure 7A, B, C and D. In both the regions - Central (Bahia State) and Lagoa Santa (Minas Gerais State) - the paintings of Cervidae are similar, even in the way the antlers are depicted. 


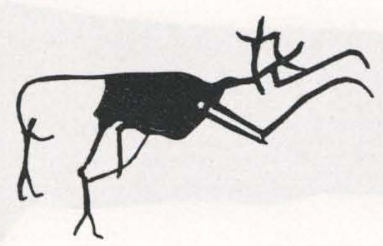

A

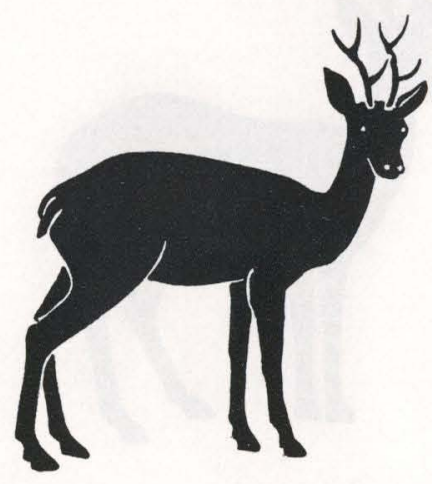

B

Fig. 9. (A) Rock painting of the Pampas Deer; (B-C) O. bezoarticus used for comparison.
Tayassuidae Palmer, 1897

Tayassu G. Fischer, 1814

Fig. 11B, C

The body is short and round, the legs short, the snout elongated and truncated, terminating in an oval surface where the nostrils are located. Ears are small and oval. The upper back bears a ridge of hair. Tail absent. These features were observed in the paintings (Fig. 11A).

This genus is proper to America from Arkansas and Texas (USA) to northern Argentina. 

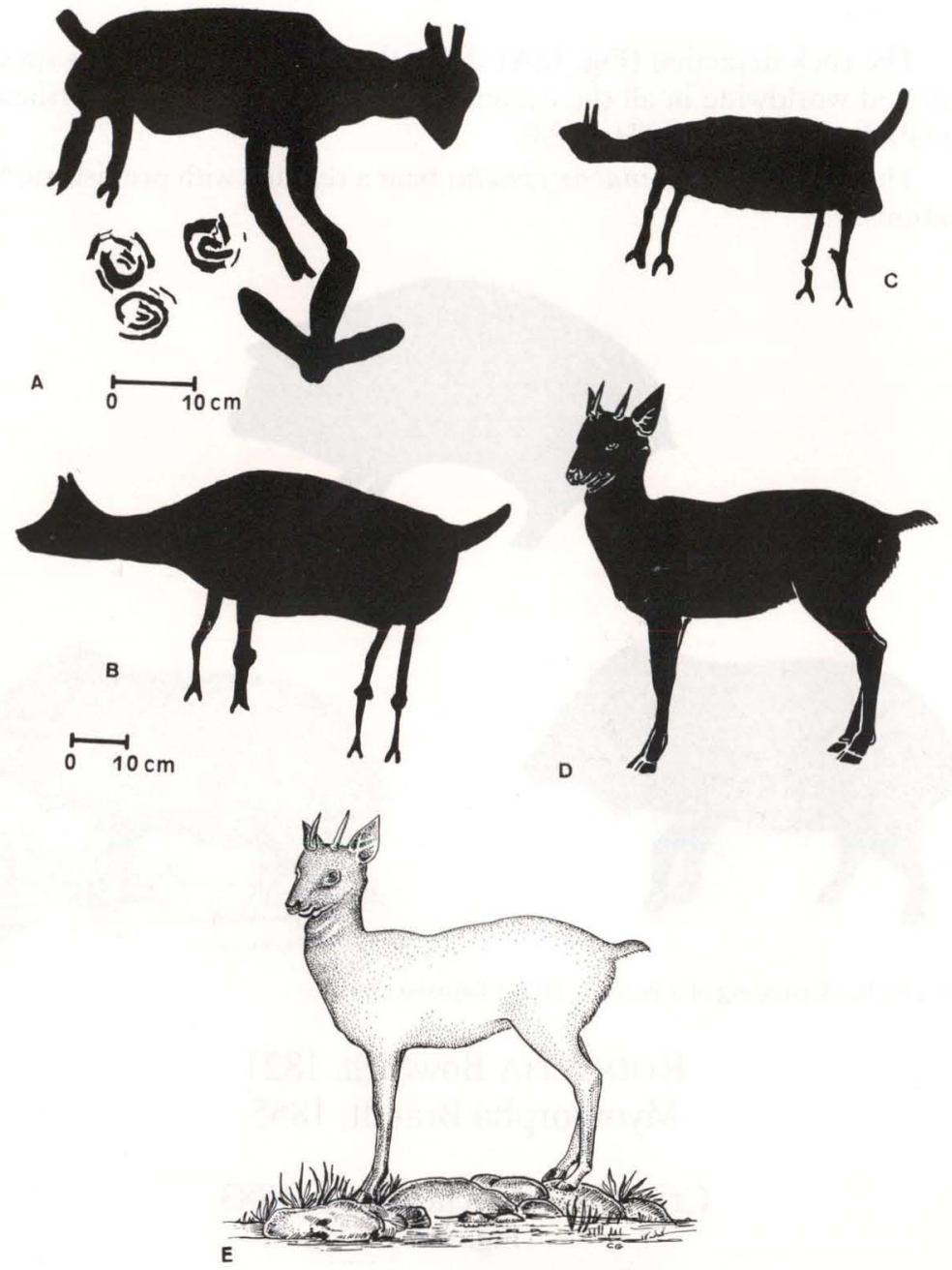

Fig. 10. (A-D) Rock painting of the Brown Brocket. (B-C) Mazama gouazubira (G. Fisher, 1814) used for comparison.

Cetacea Brisson, 1762

Physeteridae Gray, 1821

\section{Physeter macrocephalus Linnaeus, 1758}

Fig. 12

The head is massive and rectangular, ears absent, the jaw small in relation to the head size. Pectoral fins are relatively small in contrast to a tail modified into lobes and set in the horizontal plane. 
The rock depiction (Fig. 12A) shows the above features. This species is distributed worldwide in all the oceans and, in Brazil, along the northeastern coast (PALAZZO \& BOTH, 1988). migrations.

These records of $P$. macrocephalus bear a relation with prehistoric Man's
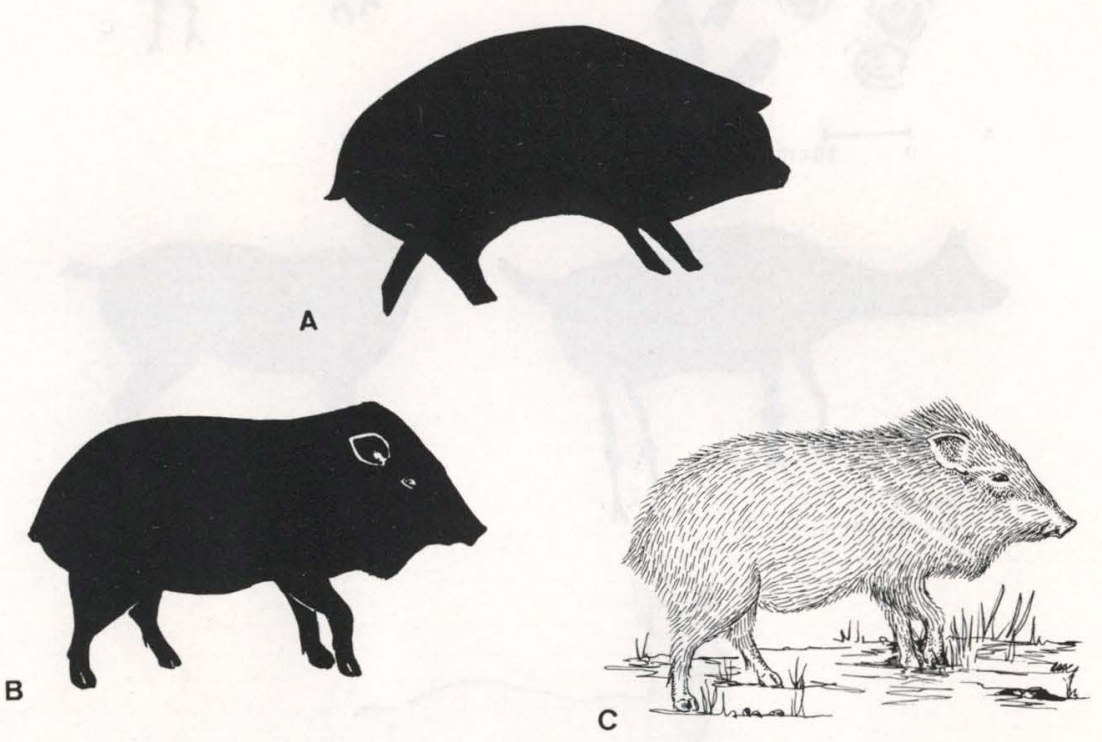

Fig. 11. (A) Rock painting of a Peccary; (B-C) Tayassu tajacu.

RODENTIA Bowdich, 1821

Myomorpha Brandt, 1855

Cricetidae Rochebrune, 1883

Fig. 13B

The rock painting in figure 13A depicts a robust body, short legs, rounded ears, long tail. We were unable to identify the species from external morphology, however, since this is very similar in all cases.

\section{HYSTRICOMORPHA Brandt, 1855}

Caviidae Waterhouse, 1839

\section{Kerodon (Cuvier, 1825)}

These are medium-sized rodents, similar to the guinea pig. They have short, rounded ears, robust bodies, short legs and a rudimentary tail. The rock paintings resemble this species (Fig. 13C). 


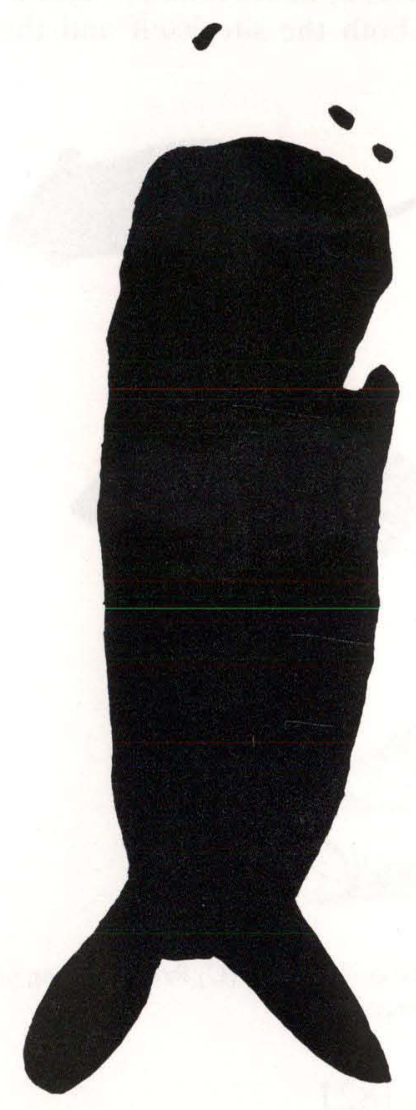

A
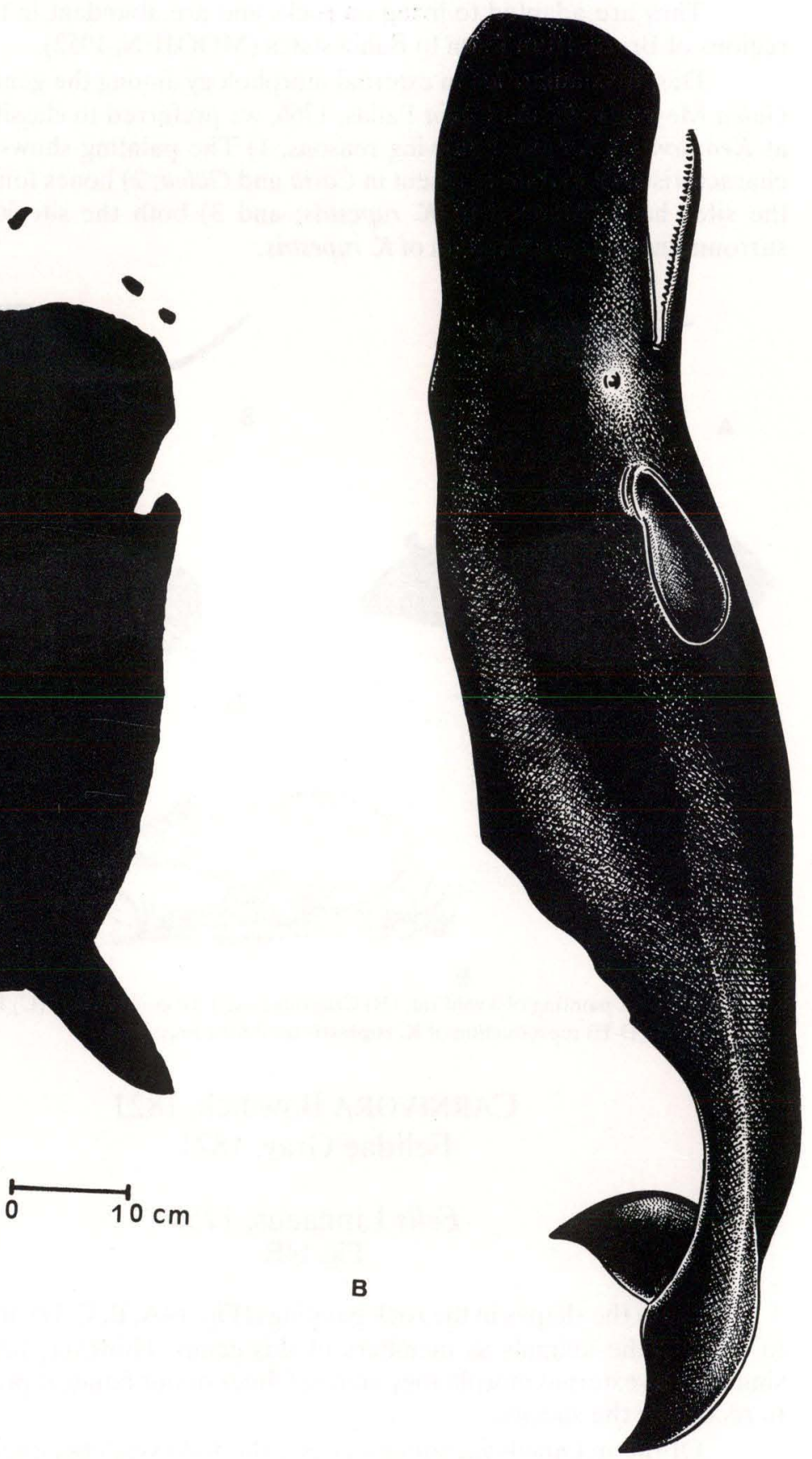

Fig. 12. (A) Rock painting of a whale; (B) P. macrocephalus used for comparison. 
They are adapted to living on rocks and are abundant in the northeast regions of Brazil, from Piauí to Bahia states (MOOJEN, 1952).

Despite similarities in external morphology among the genera Kerodon, Galea Meyen, 1832 and Cavia Pallas, 1766, we preferred to classify figure 13C as Kerodon sp. for the following reasons. 1) The painting shows a short tail, characteristic of Kerodon, absent in Cavia and Galea; 2) bones found to date at the sites have belonged to K. rupestris; and 3) both the site itself and the surrounding area are habitats of $K$. rupestris.

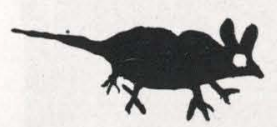

A

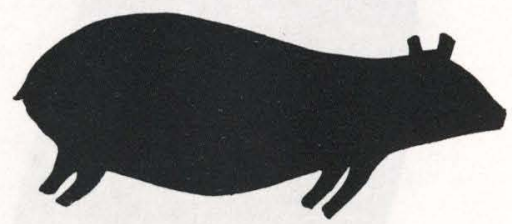

C
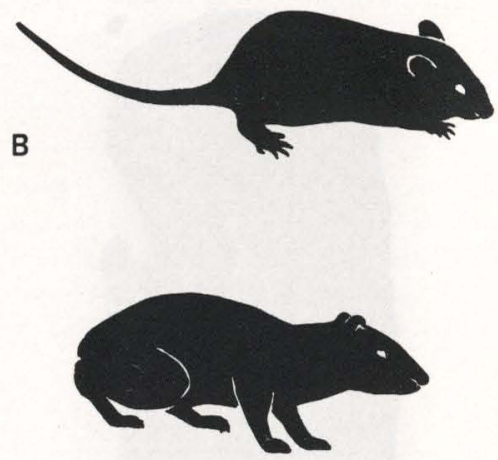

D

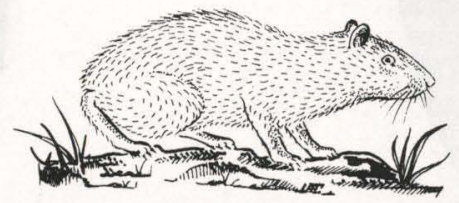

$E$

Fig. 13. (A) Rock painting of a wild rat; (B) Cricetidae used for comparison; (C) Rock painting of a Rock Cavie; (D-E) reproduction of $\mathbf{K}$. rupestris used for comparison.

CARNIVORA Bowdich, 1821

Felidae Gray, 1821

\section{Felis Linnaeus, 1758}

Fig. 14E

From the shapes in the rock paintings (Fig. 14A, B, C, D), it was possible to identify the animals as members of this genus. However, because of the similarity in external morphology among felines of our fauna, it proved difficult to recognize the species.

Of the mammals mentioned above, the following species are still to be found in the Region: M. tridactyla; M. gouazubira (G. Fisher, 1814); K. rupestris 


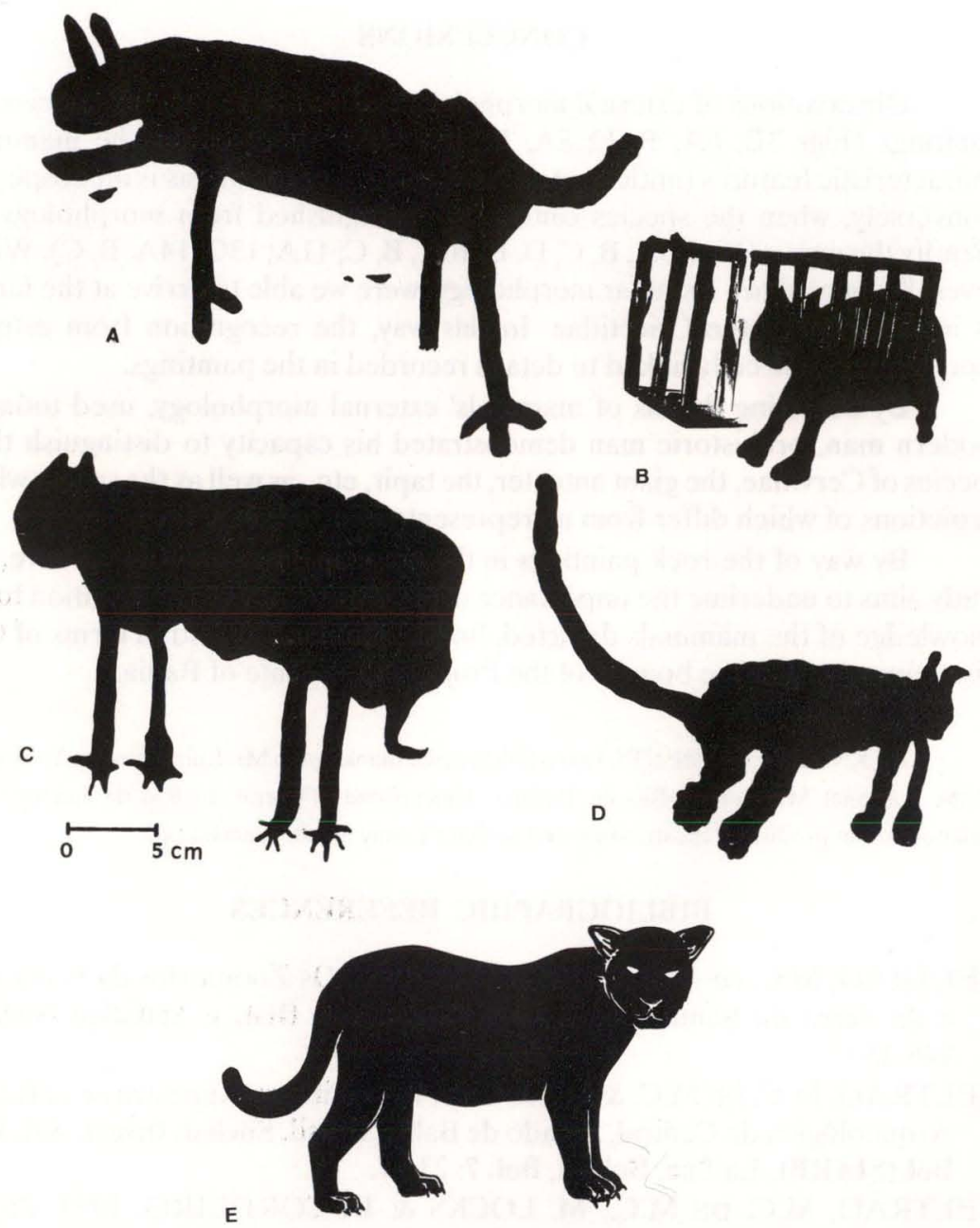

Fig. 14. (A-D) Rock painting of felids; (E) Felis onca (Linnaeus, 1758) used for comparison.

(Wied, 1820); T. tajacu; F. onca and other felids; D. septemcinctus, D. novemcinctus Linnaeus, 1758, E. sexcinctus, C. unicinctus and T. tricinctus.

To date, pictorial representations at the sites mentioned have included the following: Cervidae and Dasypodidae (hundreds); Felidae and Mimercophagidae (dozens); Tayassuidae (ten); Cricetidae and Tapiridae (three); Caviidae (two); and Physeteridae (one).

To date none of the paintings found was covered by sediment containing carbons or bones, or which might permit indirect C14 dating. It was noted, however, that the paintings had been executed by various groups of hunters during different periods, since not only are there superpositions, but the styles differ (BELTRÃO et al., 1993). 


\section{CONCLUSIONS}

Observations of external morphology enabled us to identify species in 5 paintings (Figs 3B; 6A, B, C; 8A, B; 9A; 12A) where either the mammals' characteristic features (antlers, etc.) are displayed or the genus is monospecific. Conversely, when the species cannot be distinguished from morphology, we identify the genus (Figs. 5A, B, C, D, E; 10A, B, C; 11A; 13C; 14A, B, C). Where several genera share a similar morphology, were we able to arrive at the family, as in the case of the Cricetidae. In this way, the recognition from external morphology is directly linked to details recorded in the paintings.

By depicting details of mammals' external morphology, used today by modern man, prehistoric man demonstrated his capacity to distinguish three species of Cervidae, the giant anteater, the tapir, etc., as well as the sperm whale, depictions of which differ from all representations of fish in the area.

By way of the rock paintings in the municipalities mentioned here, this study aims to underline the importance of prehistoric man's contribution to our knowledge of the mammals depicted, both taxonomically and in terms of their distribution within the bounds of the Project in the State of Bahia.

ACKNOWLEDGMENTS. Our wholehearted thanks go to Mr. Luiz Antonio Alves Costa of the National Museum of Rio de Janeiro (Universidade Federal do Rio de Janeiro) who collaborated in producing the drawings and to Peter Lenny for the translation.

\section{BIBLIOGRAPHIC REFERENCES}

BELTRÃO, M.C. DE M.C. \& T.A. LIMA. 1988. Os Zoomorfos da Serra Azul e da Serra de Santo Inácio. Rev. Patrimônio Hist. e Artístico Nac. 21: 146-157.

BELTRÃO, M.C. DE M.C. \& M. LOCKS. 1993. Pintura Rupestre en la Región Arqueológica de Central, Estado de Bahia, Brasil. Socied. Invest. Art. Rup. Bol.(SIARB), La Paz, Bolivia, Bol. 7: 23-37.

BELTRÃO, M.C. DE M.C.; M. LOCKS \& D. CORDEIRO. 1993. Project Central (Bahia, Brazil): Rock Art in the Chapada Diamantina Uplands. Soc. Bras. Arq. (SAB), Programa e Resumos: 67.

CABRERA, A. 1957. Catálogo de los Mamíferos de America del Sur. Rev. Mus. Arq. Ciênc. Nat. "Bernardino Rivadavia" e Inst. Nac. Investig. Ciênc. Nat., Ciênc. Zool. 4 (1): 1-307.

. 1960. Catálogo de los Mamíferos de America del Sur. Rev. Mus. Arq. Ciênc. Nat. "Bernardino Rivadavia" e Inst. Nac. Investig. Ciênc. Nat., Ciênc. Zool. 4 (2): 209-732.

CABRERA, A. \& J. YEPES. 1940. Mamíferos Sudamericanos. Buenos Aires, Compañía Argentina de Editores, 370p.

CARVALHO, C.T. 1979. Dicionário dos Mamíferos do Brasil. São Paulo, Nobel, 2nd. ed., 135p.

HOFFMANN, R.S. 1982. Mammal Species of the World: A Taxonomic and 
Geographic Reference. Lawrence, Allen Press, Inc. and The Association of Systematic Collectors, 1, 319p.

KOWALSKI, K. 1981. Mamíferos - Manual de Teriología. Madrid, H. Blume Ed., 1st. ed., 532p.

MONZON, S. 1987. L'art rupestre sud-américain. Pré-histoire d'un continent. Science et Découvertes, Le Rocher, Jean Paul Bertrand, 122p.

MOOJEN, J. 1952. Os Roedores do Brasil. Brasil, Ministério da Educação e Cultura, série A-II, 214p.

PALAZZO JR., J.T. \& M.C. BOTH. 1988. Guia dos Mamíferos Marinhos. Porto Alegre, Ed. SAGRA, p.45-47.

SANTOS, E. 1984. Entre o Gambá e o Macaco. Belo Horizonte, Ed. Itatiaia Ltda., Col. Zool. Brasílica, vol. 6, 287p.

SIMPSON, G.C. 1945. The Principles of Classification and a Classification of Mammals. Bull. Amer. Mus. Nat. Hist. 85: XXVI +350p.

Recebido em 25.VII.1993; aceito em 28.III. 1994. 